Wzniostość $i$ makabra w literackich obrazach śmierci, red. Michał Kuran, Łódź 2014, „Analecta Literackie i Językowe", t. IV.

\title{
CŽOWIEK ODCHODZI, PAMIĘĆ POZOSTAJE EUFEMIZMY I SYNONIMY ŚMIERCI W INSKRYPCJACH NAGROBNYCH NA CMENTARZACH W GORCACH
}

Obecny tekst przedstawia analizę napisów nagrobnych z gorczańskich cmentarzy. Materiał badawczy pochodzi z nekropolii położonych w miejscowościach: Klikuszowa, Krościenko nad Dunajcem, Lubomierz, Łopuszna, Nowy Targ (cmentarz komunalny, ul. Św. Anny), Ochotnica Górna, Ochotnica Dolna, Rabka Zdrój (cmentarz komunalny, ul. Kilińskiego 46), Rdzawka. Materiał składa się z 404 zróżnicowanych inskrypcji nagrobnych.

W cytowanych zapisach zachowany został ich oryginalny układ wesyfikacyjny oraz interpunkcja.

Kult zmarłych nie jest zjawiskiem nowym, lecz częścią kultury masowej kształtowanej na przestrzeni lat. Ostatecznym znakiem istnienia człowieka staje się mogiła, a od innych pozwala ją odróżnić umieszczony na niej napis. Inskrypcje, stają się środkiem i sposobem wyrażania bólu po stracie bliskiej osoby, są nośnikami informacji onomastycznych oraz posiadających znaczenie semiotyczne:

napis nagrobny niejako zbiera wszystkie cechy inskrypcji, od czystego nazewnictwa (epitafium onomastyczne), poprzez protokolarność (epitafium identyfikacyjne), po metaforyczno-peryfrastyczne (epitafium poetyckie). Jest to zupełnie zrozumiałe, jeśli się weźmie różnorodność nasilenia emocjonalnego związanego z osobą obdarzoną napisem nagrobnym² ${ }^{2}$.

We wszystkich kulturach do sfery tabu należą zjawiska, których ludzie nie potrafią racjonalnie wytłumaczyć, niebezpieczne, obce, skrywające pewną tajemnicę. W obliczu śmierci człowiek staje przed obiektem niemieszczącym się w granicach poznawczych. Tabu językowe występuje najczęściej tam, gdzie język pełni funkcję magiczną. Unika się zatem pewnych słów w obawie przed ich mocą lub używa słów zastępczych.

\footnotetext{
${ }^{1}$ Julita Gamoń — studentka filologii polskiej Uniwersytetu Łódzkiego (specjalizacja nauczycielska oraz glottodydaktyczna). Należy do Koła Naukowego Językoznawców UŁ. Pracuje jako trener kompetencji komputerowych, prowadząc szkolenia z obsługi komputera i korzystania z Internetu dla osób starszych. Jej zainteresowania naukowe sytuują się na styku językoznawstwa i antropologii kulturowej, czego wynikiem jest praca Wspótczesne epitafia nagrobne — analiza jezykowa inskrypcji nagrobnych na cmentarzach $w$ Gorcach.

${ }^{2}$ J. Trzynadlowski, Małe formy literackie, Wrocław 1977, s. 67-68.
} 
Człowiek wpływa tym samym na ukształtowanie otaczającej go rzeczywistości. Dzięki zastosowaniu słów równoważnych wzmocnione zostaje poczucie akceptacji pewnych zjawisk.

Słowo zawsze jest czarem: budzi niebezpieczną lub dobroczynną moc. Kto wypowiada się, ten wywiera wpływ, lecz także się naraża. Dlatego nazwy są konieczne, ale i niebezpieczne. To pozwala zrozumieć częste zakazy mówienia i używania słów, spotykane u ludów pierwotnych i antycznych. Nie wolno nazywać rzeczy i osób niebezpiecznych. Obawa przez siłą słowa jest większa niż przed siłą faktów. Słowo jest mocą decydującą. Kto wypowiada słowa, wprawia w ruch moce ${ }^{3}$.

Mimo iż, jak cytuje za Jacquesem Brehantem - Anna Engelking, autorka pracy dotyczącej eufemistycznych nazw śmierci, „przyjęto raz na zawsze, że o tym się nie mówi”“, analizując inskrypcje nagrobne nie sposób nie zauważyć różnorodności nazywania śmierci. Jacek Kolbuszewski wspomina także, że współcześnie mamy tendencje do zastępowania słowa „śmierć” eufemizmami i synonimami.

Znamienne jest obrazowanie oparte na czasownikach „zasnąc”, „spać” oraz rzeczowniku „sen”. „Sen” jest eufemizmem, bądź, jak twierdzi Anna Engelking, określaniem synonimicznym pełniącym funkcję eufemistyczną ${ }^{5}$, łagodzącym śmierć oraz osłabiającym jej znaczeniową dosadność.

Symbolika snu wywodzi się z chrześcijańskiej koncepcji umierania opartej na wierze w zmartwychwstanie ciała w dzień Sądu Ostatecznego. Jacek Kolbuszewski zauważa, iż sen zmarłego staje się niekiedy oczekiwaniem na spotkanie z jego bliskimi, których zobaczy po ich śmierci ${ }^{6}$.

Co osobliwe, czas zmartwychwstania zostaje tu skontaminowany z czasem fizycznym śmierci tych, którzy aktualnie opłakują zmarłego. Jest w takim rozumowaniu urokliwa naiwność: sen zmarłego skończy się wówczas, gdy i my zaśniemy, zaś trwający do chwili zmartwychwstania sen nas wszystkich nie będzie już snem $[\ldots]^{7}$.

„Sen” nie rozdziela ludzi „na zawsze”, tak jak w przypadku „odejścia”, lecz tylko na bliżej nieokreślony czas:

\footnotetext{
${ }^{3}$ G. van der Leeuw, Fenomenologia religii, Warszawa 1978, s. 448-449.

${ }^{4}$ A. Engelking, Istota i ewolucja eufemizmów (na przykładzie zastępczych nazw śmierci), „Przegląd Humanistyczny" 1984 , z. 4, s. 118.

${ }^{5}$ Autorka uważa, że czasowniki „spać”, „zasnąć” oraz rzeczownik „sen” „są na tyle utarte i zleksykalizowane, że trudno je jest nazwać eufemizmami” (tamże, s. 128). Za określania synonimiczne pełniące funkcje eufemistyczne uważa się także: „dokonać żywota”, „odejść”, „zgasnąć”, „spać w mogile”, „zasnąć w Panu”, „zawrzeć powieki”. Przywołuje dalej opinię J. Mac Culloch'a (cyt. za: Engelking, dz. cyt., s. 128): „U starożytnych Żydów i Greków, podobnie jak u wielu narodów współczesnych, „sen” jest eufemizmem śmierci. Wyobrażenie to z pewnością przeszło do myśli chrześcijańskiej, to że sen stał się niemal równoważnikiem śmierci, bardziej niż eufemizmem. „Spać w pokoju”, „zasnąć w Chrystusie” są zwykłymi zwrotami w epigrafice chrześcijańskiej od najdawniejszych czasów. [...] Chociaż są eufemistyczne, wyrażają radosną chrześcijańską nadzieję".

${ }^{6}$ J. Kolbuszewski, Wiersze z cmentarza, Wrocław 1985, s. 167.

${ }^{7}$ Tamże, s. 168.
} 
Ja zaś położę się i zasnę,

i obudzę się, bo wspiera mnie Bóg

Śpij dziecino mała,

bo tak Bozia chciała

Śmierć człowieka porównywana jest do „odejścia”. Jego główną cechą jest definitywne zerwanie związków między bliskimi osobami. W większości inskrypcji możemy spostrzec lekki ton skargi, ponieważ zmarły swoim „odejściem” pozostawił bliskich w żałobie:

Tak krótko żyłem,

A tak żyć chciałem.

Bóg mnie powołał

odejść musiałem.

Odszedłeś w młodości

Życia rozkwicie

A nam pozostawiłeś smutek

I łzy na całe życie

Już nie boli w błogim ukojeniu odeszłaś w ciszy, spokoju, pokorze

Pan kres położył Twojemu cierpieniu

Otul ją utul, miłosierny Boże

kochanej córeczce Mama

Inskrypcje nagrobne ukazują siłę sprawczą, którą najczęściej stanowi sam Bóg. Wyrażana jest ona czasownikami: „wezwać”, „powołać”, „zabrać”:

\footnotetext{
Zabrałeś Bożenkę

od nas jak

ranne mgły

zostawiając wielki

smutek rodzinie.

Bóg Cię powołał

w krainy nieznane

Kochałam Was bardzo,

żyć z Wami chciałam,

Bóg mnie powołał

odejść musiałam

Dałeś mi radość

Malowania obrazów świata.

Wezwana idę: malować

Twe rajskie ogrody.

Jezu ufam Tobie
} 
Wymienione symbole pełnią funkcję terapeutyczną i nobilitacyjną, gdyż zmarły został wyróżniony przez Boga spośród wielu ludzi możliwością przebywania wraz z Nim8. Możemy zatem odnależć przykłady, gdzie decyzja Stwórcy nie budzi w człowieku lęku, przeciwnie, jest dla niego miła i wyczekiwana:

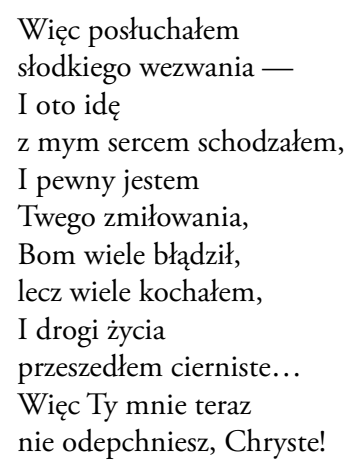

Osoby powołane przez Pana chciały najczęściej nadal cieszyć się życiem, korzystać z jego uroków, lecz nie było im to dane. Poczucie krzywdy, wyrażone najczęściej przysłówkami „za wcześnie” i „niespodziewanie”, wskazuje na brak przygotowania ludzi do śmierci własnej bądź ich bliskich i traktowane jako swoisty wyrok Boga. Wyczuwa się poczucie niesprawiedliwości, gdyż Bóg, zabierając człowieka do siebie, pozostawia jego bliskich w rozpaczy $i$ cierpieniu.

Kolbuszewski wspomina, że pojawiający się w inskrypcjach symbol „ściętego kwiatu" ma rodowód artystyczny. Wszedł on do polskiej literatury za sprawą Jana Kochanowskiego i funkcjonuje do dziś we współczesnej subkulturze cmentarnej. Związek motywu z literaturą został jednak całkowicie zatarty, jak i stosowana przez Kochanowskiego kosa ścinająca kwiaty, dziś nieobecna już w inskrypcjach':

\footnotetext{
Jak kwiat miłości wichrem miotany

Tak Cię Bóg zabrał

mężu i ojcze kochany
}

Równie ciekawym porównaniem jest motyw „zgaśnięcia gwiazdy”, stanowiący, podobnie jak poprzedni, analogię do ludzkiego życia.

Motyw ten wszedł na stałe do polskiej frazeologii (np. o kimś komu, dobrze się w życiu powodzi, powiemy — „urodził się pod szczę́liwą gwiazdą”, a o takim, któremu powodzi się źle — „urodził się pod złą gwiazdą") ${ }^{10}$. Z kolei w ludowym przeświadczeniu, ze świeceniem gwiazd i ich obecnością na niebie związane jest przekonanie, że

\footnotetext{
${ }^{8}$ Tamże, s. 174 .

${ }^{9}$ Tamże, s. 175.

${ }^{10}$ S. Niebrzegowska, Gwizady w ludowym językowym obrazie świata, [w:] Językowy obraz świata, red. J. Bartmiński, Lublin 1999, s. 140.
} 
każdy człowiek ma swoją gwiazdę, która zapala się na niebie z chwilą jego narodzin [...]. Gwiazda jest maleńka, kiedy człowiek jest mały, potem z jego wzrostem — powiększa się. Gdy ktoś jest chory i źle mu się powodzi, jego gwiazda świeci mdło, gdy jest zdrowy i szczęśliwy — świeci jasno [...]. Gdy człowiek na ziemi umiera, gwiazda jego gaśnie i spada $[\ldots]^{11}$.

\section{Porównawczo:}

Zgasłeś tak szybko

Jak gwiazdka na niebie

Śpij spokojnie

Ja przyjdę do Ciebie

Śpij serce moje

dla Ciebie świt złoty

raz tylko błysnął i wnet

zgasł w półmroku

I nie pozostawił nic

oprócz tęsknoty

Najukochańszemu mężowi

Żona i dzieci

Śmierć w ujęciu inskrypcyjnym nie jest definitywnym zakończeniem życia. Wyrażenia, takie jak: „wieczna chwała”, „wieczny byt”, „pokój wieczny”, „życie wieczne”, „wieczne odpoczywanie”, „wieczne spoczywanie” wskazują na przejście z jednego świata do drugiego. Według religii chrześcijańskiej, poprzedzone jest ono sądem szczegółowym Chrystusa, Sędziego żywych i umarłych, a usankcjonowanym przez Sąd Ostateczny, który odbędzie się przy końcu świata. Analizowane epitafia uwidaczniają, że śmierć człowieka na ziemi nie jest ostatecznym etapem, lecz jedynie przejściem do lepszego życia, nieograniczonego w czasie i nieprowadzącego do ponownego odejścia, życia pozbawionego ziemskich trudów i kłopotów:

Źródło życia Panie nasz

Ty nam wieczne życie dasz

W Tobie mój Panie

znajdę pokój wieczny

Nad Twoją mogiłą, o matko

Zgasłe kochanie za całą

Twoją miłość modlitwa

Boże daj wieczne odpoczywanie

Tej co swej

dziecinie niosła

myśl, serce,

czyn, życie,

${ }^{11}$ Tamże. 
daj Panie

ciszę błogą

i szczęście

w Wiecznym Bycie

Śmierć staje się niekiedy dla człowieka „odpoczynkiem”, czasem „odpoczywania”, rozumianym jako przerwanie pewnej pracy, uwolnienie się od wykonywania określonych czynności, oderwanie się od trudów, cierpienia i bólu napotkanych w ziemskim życiu. Dopiero „wtedy” może spokojnie „odpocząc””, co uwidaczniają wyrażenia: „spoczywaj w Bogu”, „spoczywaj w pokoju”, „spoczywaj w Pokoju Wiecznym”:

Odpoczywam po życiu

w trudzie, w ciagłym biegu

Ja tu nie na stałe

jeno na noclegu.

Niech odpoczywa w pokoju wiecznym

Spoczywaj w Bogu

Byłaś filarem naszej

rodziny Mamo Kochana.

Nauczyłaś nas miłości, pracy,

cierpienia.

Spoczywaj w Pokoju Wiecznym.

Zakończenie życia wyraża także rzeczownik „rozłąka”, symbol dający nadzieję na powrót bliskich, ukazujący jedynie sytuację oddalenia ludzi od siebie. Bez względu na czas, jaki oznacza, istnieje szansa na ponowne spotkanie:

Rozłąka jest naszym losem

Spotkanie naszą nadzieją

„Rozłąka” nie jest stanem ostatecznym, podobnie jak „rozstanie”, które posiada jednak dwa aspekty czasowe, chwilowy i stały. Jedynie pierwszy z nich ukazywany był w inskrypcjach:

Bolesne było nasze rozstanie

Lecz taka wola była Panie

Wierząc, że kiedyś się spotkamy

Żona z synem

Metaforyzacji ulega sam moment zakończenia życia przez człowieka. Wskazuje to na pewien kończący się okres, moment czy cykl wyrażony jako „godzina”, „ostatnia godzina” lub ,godzina rozstania”:

Nie płaczcie serca...

Wszak tym, co pomarli

Modlitwy trzeba — nie łez rozpaczy! 
Módlcie się szczerze, aż przyjdzie godzina,

Gdy ich do siebie Pan powołać raczy

Odeszłaś od nas

bez słów pożegnania

jak ta co nie chce swą rozłąką smucić

jak ta co wierzy

w godzinę rozstania

z dobrą wieścią wrócić

Cześć Jej pamięci

Ostatnia godzina za szybko wybiła,

Lecz wola Boża tak uczyniła

Jednak oprócz synonimów i eufemizmów łagodzących proces umierania, w epitafiach pojawiają się określania wzmagające drastyczność i dosadność śmierci, jak i w niektórych przypadkach wskazuje się na „śmierć” jako czynnik rozdzielający bliskich, o czym była mowa wyżej:

Gdyby miłość

Mogła czynić cuda

A łzy budzić umarłych ze snu

Nie spoczywałbyś tu

Wszystko co najdroższe

W tym grobie się mieści

Śmierć zabrała wszystko

Oprócz łez boleści

Życie mija, czas upływa

śmierć zabija, wieczność wzywa

Boże zbaw jego

duszę.

Najdroższemu mężowi

żona z dziećmi

Liczną grupę stanowią napisy ze skonkretyzowanym powodem, rodzajem czy miejscem „śmierci”. Część z nich rozpoczyna się lub posiada w swojej konstrukcji czasownik „zginąć”, bezpośrednio oznaczający poniesienie śmierci, utratę życia:

Zginął z rąk bandy ognia

śmiercią męczeńską

Zginąt śmiercią lotnika

Zginęła śmiercią tragiczną

Naturalizm umierania podkreślają wyrażenia, takie jak: „ciemny grób”, „zimna mogiła”. Wywołują silne emocje u odbiorcy, ale także sytuują zmarłego w aurze samotności i opuszczenia, wskazując na miejsce spoczynku jako pozbawione jasności i chłodne: 
Śpij żołnierzu w ciemnym grobie

Niech się Polska przyśni Tobie

Ta zimna mogiła kryje

wszelkie marzenia i nadzieje

rodziny bolejącej nad stratą

kochanego syna i brata

Na językowy obraz śmierci składają się synonimy oraz eufemizmy śmierci i umierania. Oto częstotliwość ich występowania wraz z zabarwieniem emocjonalnym - dodatnim (+) lub ujemnym (-) zależnym od kontekstu, w jakim dane słowo lub wyrażenie zostało użyte oraz jego znaczenia.

Tabela 1.

\begin{tabular}{|c|c|c|}
\hline $\begin{array}{c}\text { Rzeczowniki / } \\
\text { wyrażenia } \\
\text { rzeczownikowe }\end{array}$ & $\begin{array}{c}\text { Częstotliwość } \\
\text { występowania }\end{array}$ & Zabarwienie \\
\hline Błogi sen & 1 & + \\
\hline Bolesne rozstanie & 1 & - \\
\hline Godzina & 1 & + \\
\hline Godzina rozstania & 1 & - \\
\hline Ciemny grób & 2 & - \\
\hline Odpoczynek & 1 & + \\
\hline Ostatnia godzina & 1 & $+/-$ \\
\hline Pokój wieczny & 4 & + \\
\hline Rozłąka & 1 & $+/-$ \\
\hline Rozstanie & 2 & $+/-$ \\
\hline Strata & 1 & - \\
\hline Śmierć & 12 & - \\
\hline Śmierć męczeńska & 1 & - \\
\hline Zaśnięcie & 1 & + \\
\hline Zimna mogiła & 1 & + \\
\hline Życie wieczne & 3 & + \\
\hline Wezwanie & 1 & + \\
\hline Wieczna chwała & 2 & + \\
\hline Wieczny byt & 1 & + \\
\hline $\begin{array}{l}\text { Wieczny } \\
\text { odpoczynek }\end{array}$ & 2 & + \\
\hline Wieczny pokój & 1 & + \\
\hline $\begin{array}{l}\text { Wieczne } \\
\text { odpoczywanie }\end{array}$ & 2 & + \\
\hline
\end{tabular}




\begin{tabular}{|c|c|c|}
\hline $\begin{array}{c}\text { Wieczne } \\
\text { spoczywanie }\end{array}$ & 1 & + \\
\hline Wieczne życie & 1 & + \\
\hline
\end{tabular}

\begin{tabular}{|c|c|c|}
\hline Przymiotniki & $\begin{array}{c}\text { Częstotliwość } \\
\text { występowania }\end{array}$ & Zabarwienie \\
\hline błogi & 1 & + \\
\hline ciemny & 2 & - \\
\hline męczeński & 1 & - \\
\hline ostatni & 1 & - \\
\hline wieczny & 18 & + \\
\hline zimny & 1 & - \\
\hline Czasowniki & Częstotliwość & Zabarwienie \\
\hline Odejść & 31 & $+/-$ \\
\hline Odpoczywać & 1 & + \\
\hline Pomrzeć & 1 & - \\
\hline Powołać & 7 & + \\
\hline Spać & 9 & + \\
\hline Spoczywać & 8 & + \\
\hline Umierać, umrzeć & 6 & - \\
\hline Wezwać & 3 & + \\
\hline Zabrać & 25 & - \\
\hline Zasnąć & 1 & + \\
\hline Zgasnąć & 2 & + \\
\hline Zginąć & 5 & + \\
\hline
\end{tabular}

Julita Gamoń

\section{Ein Mensch geht, die Erinnerung bleibT. Euphemismen und Synonyme des Todes auf Grabinschriften aUf den FriedhöFen in GorCE}

\section{Zusammenfassung}

Das oben formulierte Thema wurde nach einer Auswertung der Grabinschriften auf den Friedhöfen in Gorce ausgearbeitet. Das Forschungsmaterial kam von Friedhöfe, die sich in folgenden Orten befinden: Klikuszowa, Kroscienko am Dunajec, Lubomierz, Lopuszna, Nowy Targ (städtischer Friedhof, auf der Sw. Anna-Straße), Ochotnica Górna, Ochotnica Dolna, Rabka Zdrój (städtischer Friedhof, auf der Kilinski 46-Straße), Rdzawka.

Das Ganze umfasst 404 verschiedenen Grabinschriften.

Die Auswertung enthält Euphemismen und Synonyme des Todes, die den Prozess des Sterbens mildern sollen, so wie die, die Natürlichkeit und Drastik des Todes betonen (unter anderem: das ewige Leben, Motiv des erlöschenden Sterns und Schnittblume, das dunkele Grab, die Ruhe, letzte Stunde, der ewige Frieden, berufen, Schlaf, schlafen, ewiger Ruhm, rufen, wegnehmen, das ewige Leben). 